\title{
BERBAGAI PANDANGAN TENTANG PENDIDIKAN
}

Djohar Maknun

Pendidik Thomistik didasarkan pada filsafat Aristoteles dan kitab suci Kristen. Berdasarkan antiseden teistiknya, Thomisme menegaskan bahwa pendidikan harus membantu orang-orang untuk mendapatkan hidup yang supernatural. Penganut Realisme menegaskan bahwa karakteristik yang membedakan manusia adalah pendidikan. Pendidikan seharusnya memberikan kontribusi untuk kehidupan yang intelektual. Sebuah pendidikan yang lengkap juga harus memfasilitasi partisipasi aktif setiap orang, baik dalam budaya maupun perkembangan diri. Meskipun merekomendasikan pendidikan yang intelektual, Thomisme mengakui bahwa manusia adalah manipulator dari lingkungan alam dan pencipta budaya. Sebagai seorang manipulator atau pekerja, manusia praktis membutuhkan beberapa persiapan untuk pekerjaan dan kehidupan profesionalnya (Gutek, 1974:58)

Para siswa yang berada pada jenjang pendidikan dasar berada pada usia sekitar 6 sampai dengan 15 tahun. Mereka berada pada tahap usia anak sekolah (6-12 tahun) dan remaja awal (12-15 tahun). Anak-anak pada usia ini mengalami perkembangan fisik dan motorik yang sangat cepat. Mereka merupakan anak-anak yang secara fisik sehat, aktif, dan lincah. Keterampilan motoriknya juga berkembang sangat cepat. Stanley Hall (Sukmadinata 2007:117) menyebut usia SD sebagai masa pemburu karena anak-anak suka memburu binatang, mencari dan mengumpulkan batu-batuan, kerang, tanaman, dan sejenisnya. Adapun usia SLTP disebut Rousseau (Sukmadinata 2007:117) sebagai manusia petualang karena para remaja ini senang berpergian, piknik, mendaki gunung, menelusuri sungai, pantai, dan lain-lain.

Dalam perkembangan berpikir, pada usia SD awal (6-7 tahun) kemampuan berpikir anak berada pada tahap pemikiran intuitif atau berpikir khayal. Anak sangat kaya dengan fantasi dan setiap benda dapat diperankan sebagai apa saja. Sebuah kursi, selain dijadikan tempat duduk, dapat diperankan sebagai mobil, kereta api, pesawat terbang, perahu, kapal laut, dan sebagainya. Pada usia SD selanjutnya (7-12 tahun) kemampuan berpikir anak lebih tinggi, tetapi terbatas pada berpikir konkret. Anak belum mampu berpikir abstrak (Piaget, dalam Sukmadinata 2007:118). Mereka sudah menguasai operasi-operasi hitungan seperti menambah, mengurang, mengali, membagi, menyusun, mengurutkan, bahkan memangkatkan dan mencari akar bilangan yang sederhana. Penggunaan media pembelajaran sangat dibutuhkan dalam proses pembelajaran pada masa ini. Pada usia SLTP 
para remaja kecil sudah mampu berpikir formal. Pemikirannya berangsur sempurna: ia telah dapat berpikir abstrak, berpikir deduktif dan induktif, berpikir analitis dan sintesis, berpkir hipotesis, serta konvergen dan divergen walaupun masih dalam tahap awal (Sukmadinata 2007:256).

Anak-anak pada usia SD cepat sekali mengenal dan menghafal nama orang, benda, binatang, tanaman, dan sebagainya, apalagi kalau disertai dengan peragaan. Kemampuan berbahasa anak dimulai dengan dengan bahasa lisan (mendengarkan dan berbicara), baru kemudian membaca dan menulis (Sukmadinata 2007:257). Aspek sosial juga berkembang sangat pesat. Usia SD dan SLTP merupakan masa hidup berkawan (membentuk kelompok sebaya). Pada usia SD kelas rendah ikatan anak dengan orang tua agak longgar dan semakin longgar pada usia kelas-kelas tinggi. Anak-anak pada usia ini mulai melepaskan diri dari hubungannya dengan orang tua dan meningkatkan ikatannya dengan teman-teman sebaya.

Perkembangan aspek moral dan keagamaan berjalan sejajar dengan perkembangan aspek-aspek lainnya (kognitif, sosial, dan bahasa). Perkembangan aspek-aspek ini sangat dipengaruhi oleh faktor lingkungan, baik lingkungan, keluarga, sekolah, maupun teman sebaya. Pada mulanya anak melakukan perbuatan bermoral atau keagamaan karena meniru, baru kemudian menjadi perbuatan atas prakarsa sendiri. Perbuatan prakarsa sendiri ini pun pada mulanya dilakukan karena ada kontrol atau pengawasan dari luar, kemudian berkembang, karena kontrol dari dalam atau dirinya sendiri.

Helms \& Turner (1981:282), dengan merujuk pada tahap-tahap perkembangan moral dari Kohlberg, menyimpulkan bahwa pada usia SD anak sudah mampu berbuat baik kerna ingin mendapatkan balasan (naivelly egoistic), dan pada usia SLTP anak berbuat baik karena mematuhi peraturan dan hukum (respect for authority and social order). Tahapan selengkapnya dari perkembangan moral menurut Kohlberg (Sukmadinata 2007:119) dari yang terendah adalah (1) untuk menghindari hukuman dan mendapatkan ganjaran, (2) sebagai alat untuk mencapai tujuan pribadi, (3) agar dinilai baik atau mendapatkan pujian, (4) kepatuhan pada peraturan dan hukum, (5) mematuhi perjanjian masyarakat, dan (6) berbuat mengikuti kata hati.

Merujuk pada penjelasan tentang pendidikan dasar di atas, maka kelebihan Thomisme jika dikaitkan dengan pendidikan dasar di Indonesia, yaitu: a) alamiah, pendidikan pada dasarnya mempersiapkan manusia untuk menjadi dan melakukan sesuatu, sehingga mencapai akhir kehidupan yang luhur. Jelaslah bahwa tidak akan ada pendidikan sejati jika tidak sepenuhnya diarahkan untuk kehidupan akhir manusia; b) mendasarkan pada wahyu. Sebagai takdir, Allah telah menyatakan diri-Nya dalam Pribadi Putra Tunggal-Nya, yakni 
"jalan, kebenaran, dan hidup". Pendidikan sempurna adalah pendidikan Kristen; c) Ilahiah, tujuan akhir dari pendidikan Kristen adalah agar dapat bekerja sama sesuai dengan rahmat Ilahi dalam membentuk Kristen yang benar dan sempurna, yaitu untuk membentuk regenerasi Kristen melalui baptisan; d) Kristus, produk dari pendidikan Kristen adalah orang supernatural yang berpikir, menentukan, dan bertindak terus-menerus dan konsisten seperti contoh dan ajaran Kristus; dan e) ruang lingkup, pendidikan Kristen meliputi seluruh aspek kehidupan manusia, baik fisik dan spiritual, intelektual dan moral, individu, rumah tangga maupun sosial. Pembelajaran seperti ini di tingkat pendidikan dasar sangat baik karena dapat membentuk dan membiasakan anak untuk menjadi individu yang sempurna. Anak diharapkan selalu berpikir dan berperilaku seperti yng dicontohkan oleh Tuhan (Gutek, 1974:52)

Mendasarkan pada salah satu kitab suci atau salah satu agama merupakan kekurangan dari Thomisme. Indonesia merupakan negara multi-agama, sedangkan Thomisme berpusat pada ajaran salah satu agama. Hal ini tentu saja akan menimbulkan ketidakharmonisan. Penggunaan pendapat dari tokoh ini dalam dunia pendidikan secara tidak langsung akan terkesan seperti juga memaksakan agama kepada orang lain. Meskipun pendidikan agama sedari dini perlu dilakukan, tetapi jangan mendoktrin kepada anak. Thomisme terkesan mendoktrin dan mengajarkan satu agama. Hal ini tentu saja bertentangan dengan Undangundang yang berlaku di Indonesia.

Pandangan Pendidikan Progresivisme (Gutek, 1974:146-47)

a. Konsep

Progresivisme mengusung konsep: 1) anak diberi kebebasan untuk berkembang secara alami; 2) minat siswa dirangsang dengan pengalaman langsung, yang merupakan rangsangan terbaik untuk pembelajaran; 3) guru menjadi sumber atau pemandu dalam aktivitas pembelajaran; 4) ada kerja sama antara sekolah dengan keluarga; 5) sekolah menjadi sebuah laboratorium untuk bereksperimen dan sarana dalam memperbaiki sistem pendidikan. Prinsip ini menjadikan sekolah sebagai tempat yang menyenangkan sehingga anak akan bebas untuk melakukan eksperimen, bermain, dan mengekpresikan diri mereka sendiri; 6) tidak menekankan pada subjek atau mata pelajaran, tetapi menekankan anak sebagai pembelajar; 7) menekankan pada aktivitas dan pengalaman daripada keterampilan verbal dan literasi; 8) mendorong pembelajaran kelompok daripada kompetisi belajar secara individual serta kemajuan. 


\section{b. Tujuan}

Progresivisme bertujuan mendidik individu sesuai minat dan kebutuhan. Siswa mempunyai kesempatan yang luas untuk mengembangkan bakat dan minat sebagai aktualisasi diri. Sekolah merupakan tempat belajar siswa untuk memperoleh pengetahuan. Hal ini dilakukan melalui proses interaksi antara seorang siswa dengan lingkungan atau seorang siswa dengan pengalamannya. Oleh karena itu, progresivisme tidak menekankan pada "apa yang dipikirkan", tetapi pada "bagaimana berpikir". Siswa dibekali keterampilan-keterampilan untuk memecahkan masalah. Selain itu, progresivisme juga memberi manfaat agar dapat berinteraksi dengan lingkungan yang mengalami perubahan dan berlangsung secara terus-menerus. Keterampilan pemecahan masalah yang diberikan dapat digunakan oleh siswa untuk menentukan, menganalisis, dan memecahkan permasalahan, dengan proses pembelajaran yang didasarkan pada minat dan kebutuhan siswa.

c. Kurikulum

Pendidikan menekankan pada minat dan kebutuhan siswa. Penekanan yang lebih diperhatikan adalah pada aktivitas anak, kreativitas, dan belajar dari pengalaman melalui interaksi dengan lingkungan, baik alam maupun sosial.

\section{d. Peran Guru}

Guru tidak memegang otoritas penuh terhadap murid. Guru lebih sebagai pembimbing, penasihat, dan pengarah bagi siswa. Pendidik sebaiknya sebagai pengarah dalam kegiatan diskusi, merencanakan, dan melaksanakan pembelajaran. Pendidik harus menciptakan suasana pembelajaran yang kondusif, dan memberikan lingkungan belajar terbaik bagi siswanya. Dalam membimbing, guru tidak boleh menguasai, mendominasi, atau menonjolkan diri. Pendidik harus lebih bersikap demokratis dan memperhatikan hak-hak peserta didik secara keseluruhan. Pendidik lebih memberikan motivasi kepada siswa dalam pemecahan masalah, agar tidak mudah menyerah ketika mengalami kendala dalam menyelesaikannya. Guru lebih menekankan pada minat dan bakat siswa daripada materi pelajaran. Oleh karena itu, guru bersama siswa, atau melalui orang tua dapat menentukan dan mengembangkan program belajar yang akan ditempuh sebagai bentuk aktualisasi diri siswa terhadap minat dan kebutuhannya. Penilaian hasil belajar dilakukan dalam aspek mental, fisik, moral, dan perkembangan sosial, bukan hanya sekadar ranah kognitif. Hasil penilaian kemudian dievaluasi oleh guru untuk merefleksikan kegiatan pembelajaran yang sudah dilakukan, dengan 
menentukan pola pembelajaran yang akan diterapkan pada tahap selanjutnya. Dengan demikian, guru harus kreatif.

Pandangan Pendidikan Rekonstruksionisme sosial/kultural (Gutek, 1974:174-176)

a. Konsep

Pendidikan merupakan produk dari suatu masa dan kontekstual terhadap lingkungan budaya tertentu. Oleh karena itu, rekonstruksionisme melihat pendidikan sebagai sarana untuk memelihara kemasyarakatan sebagai mana adanya. Perubahan besar diperlukan untuk membentuk suatu masyarakat yang lebih responsif terhadap kebutuhan individu. Reformasi pendidikan tidak dapat dipisahkan dari reformasi sosial.

b. Tujuan

Aliran rekonstruksionis menekankan pada kebutuhan untuk perubahan, yaitu perubahan sosial dan tindakan sosial. Pemikiran untuk mengembangkan perubahan didasarkan atas pemikiran bahwa individu dan masyarakat akan dapat membuat suatu perubahan yang lebih baik. Dengan demikian, rekonstruksionisme akan melibatkan lebih banyak masyarakat sebagai agen perubahan (change-agents), untuk mengubah diri sendiri atau dunia di sekitar mereka. Para rekonstruksionis melihat pendidikan sebagai sesuatu yang melibatkan individu dan masyarakat.

c. Kurikulum

Kurikulum ditekankan pada kebenaran, persaudaraan, dan keadilan. Kurikulum harus diorientasikan pada tindakan oleh keterlibatan siswa dalam proyek-proyek. Jika diperlukan, guru meminta siswa untuk membaca literatur dari bangsa lain, baik dalam hal ekonomi, sosial, maupun budaya. Hal ini sebagai salah satu upaya untuk mengetahui dan membentuk perubahan sosial. Oleh karena itu, kurikulum akan terus berubah yang diselaraskan antara tujuan-tujuan nasional dengan tujuan siswa.

d. Peran Guru

Para pendidik sebagai reformer pendidikan yang radikal. Guru sebagai perubah yang nyata dalam masyarakat. Oleh karena itu, guru terlibat secara efektif, baik sebagai pendidik maupun aktivis sosial. Guru harus membuat para peserta didik menyadari masalah-masalah yang dihadapi umat manusia. Guru harus terampil dalam membantu peserta didik menghadapi berbagai kontroversi dan perubahan. Guru harus menumbuhkan perbedaan dalam kemampuan berpikir sebagai suatu cara untuk menciptakan alternatif-alternatif pemecahan masalah yang menjanjikan keberhasilan. 


\section{Pendidikan Tinggi}

Pendidikan tinggi merupakan pendidikan formal yang menyelenggarakan program pendidikan diploma, sarjana, magister, spesialis, dan doktor. Pendidikan tinggi diselenggarakan dengan sistem terbuka. Satuan pendidikan yang menyelenggarakan pendidikan tinggi disebut perguruan tinggi yang dapat berbentuk akademi, politeknik, sekolah tinggi, institut, atau universitas. Perguruan tinggi berkewajiban menyelenggarakan pendidikan, penelitian, dan pengabdian kepada masyarakat (Tridharma Perguruan Tinggi). Perguruan tinggi dapat menyelenggarakan program akaedmik, profesi, dan/atau vokasi (UUSPN 20/2003, Pasal 20).

Dalam penyelenggaraan pendidikan dan pengembangan ilmu pengetahuan, pada perguruan tinggi berlaku kebebasan akademik dan kebebasan mimbar akademik serta otonomi keilmuan. Perguruan tinggi memiliki otonomi untuk mengelola sendiri lembaganya sebagai pusat penyelenggara pendidikan tinggi, penelitian ilmiah, dan pengabdian kepada masyarakat. Perguruan tinggi dapat memperoleh dana dari masyarakat, yang pengelolaannya dilakukan berdasarkan prinsip akuntabilitas publik (UUSPN 20/2003, Pasal 24)

Tujuan pendidikan tinggi adalah (1) menyiapkan peserta didik menjadi anggota masyarakat yang memiliki kemampuan akademik dan/atau profesional yang dapat menerapkan, mengembangkan dan/atau memperkaya khasanah ilmu pengetahuan, teknologi dan/atau kesenian, dan (2) mengembangkan dan menyebarluaskan ilmu pengetahuan, teknologi dan/atau kesenian serta mengupayakan penggunannya untuk meningkatkan taraf kehidupan masyarakat dan memperkaya kebudayaan nasional.

Merujuk pada penjelasan tentang pendidikan tinggi seperti yang diuraikan di atas, maka aliran filsafat yang mungkin dapat diterapkan adalah rekonstruksionisme sosial/kultural. Hal ini mendasarkan pada konsep pendidikan rekonstruksi itu sendiri. Mahasiswa adalah pembelajar dewasa. Sebagai pembelajar dewasa, mahasiswa diharapkan telah memiliki karakter. Oleh karena itu, pendidikan dewasa lebih berfokus pada interaksi sosial serta penyelesaian berbagai masalah sosial. Brameld (1971) yang menyatakan bahwa manusia merupakan pencipta dan penghancur peradaban. Hal ini sejalan dengan Hamalik (2007: 62) yang menyatakan bahwa sekolah merupakan agen perubahan (change agents) dalam rekonstruksi sosial. Rekonstruksi ini hendaknya tetap dengan mempertahankan ciri atau karakter ke-indonesia-an. 


\section{Filsafat pendidikan Ki Hadjar Dewantara dan Driyarkara}

Kedua filsafat pendidikan tersebut saling melengkapi. Ki Hadjar Dewantara berprinsip bahwa pendidikan hendaknya menguatkan pada penanaman nilai-nilai luhur yang dimiliki oleh bangsa sendiri. Hal ini sebagai salah satu usaha memanusiakan manusia. Pendidikan memberikan kemerdekaan kepada anak didik walaupun tidak leluasa. Batasan yang diberikan terkait kodrat alam. Para siswa tidak boleh melupakan ideologi kebangsaanya masing-masing yang memiliki ciri khas dari bangsanya. Menurut Ki Hadjar Dewantara: "...pengajaran harus bersifat kebangsaan..., kalau pengajaran bagi anak-anak tidak berdasarkan kenasionalan, maka anak-anak tak mungkin mempunyai rasa cinta bangsa, dan makin lama terpisah dari bangsanya, kemudian barangkali menjadi lawan kita..." . Di sini perlu berhati-hati sebab dapat merusak budaya bangsa (Suratman, 1985).

Dalam filsafat pendidikan Ki Hadjar Dewantara dikenal dengan sistem among, dimana siswa diibaratkan seperti tanaman. Seorang petani yang baik memahami karakteristik tanaman, begitu juga seorang pendidik harus memahami karakteristik peserta didiknya.

Jika Ki Hadjar Dewantara berfokus pada nilai-nilai luhur bangsa, jangan sampai kehilangan jati diri, maka Driyarkara melengkapi dengan berfokus pada pribadi, cinta kasih, dan kesadaran diri. Seorang individu hendaknya menyadari bahwa keberadaannya turut mempengaruhi lingkungan, baik manusia lain maupun alam. Oleh karena itu, pendidikan hendaknya berfokus pada pembangunan diri sehingga dapat bermanfaat bagi diri dan lingkungan. Pendidikan berdasarkan pemikiran filsafat Driyarkara dirancang tidak hanya sekedar untuk memenuhi kebutuhan pragmatis yang bersifat sementara, misalnya untuk memenuhi kebutuhan ekonomi dan profesi, proses pendidikan harus benar-benar membantu perkembangan anak didik dalam menjalani proses hominisasi dan humanisasi (Supratiknya, 2014) . Dasar-dasar pendidikan karakter harus menjadi fokus proses pendidikan peserta didik. Jadi, merujuk pada penjelasan di atas sebelumnya, dapat diketahui bahwa filsafat pendidikan Ki Hadjar Dewantara lebih menganut kepada aliran pragmatism, sedangkan Driyarkara pada aliran existensialism.

\section{Kelebihan dan kekurangan pandangan Open Education dan Deschooling Society}

Kelebihan Open Education (Gutek 1974: 246-251)

1. Kebebasan bagi peserta didik untuk memperoleh pendidikan dari lingkungan keluarga (sebagai pendidik pertama) dan lingkungan masyarakat dimana anak bersosialisasi dengan lingkungan sekitar.

2. Pembelajaran bersifat kritis, konstruktivis, dan nyata. 
3. Sekolah sebagai tempat mengembangkan rasa ingin tahu, kemampuan talenta, minatminat peserta didik, merasakan keragaman dan kekayaan bersama orang-orang dewasa dan anak yang lebih tua di lingkungan sekitarnya.

4. Sekolah menjadi pusat aktivitas intelektual, seni, kreativitas dan olahraga, sesuai keinginan peserta didik. Sekolah menjadi tempat yang nyaman dan aman bagi pengembangan bakat dan semangat belajar anak untuk terus belajar.

Kelebihan Deschooling Society (Gutek 1974: 252-260)

1. Memudahkan orang tua dalam menyesuaikan dengan kebutuhan masing-masing anak.

2. Orang tua dapat mengatur jadwal pelajaran sesuai kebiasaan anak.

3. Orang tua dapat menyesuaikan metode pembelajaran dengan karakter anak.

4. Orang tua dapat memberikan materi sesuai dengan tingkatan akademik anak.

5. Memperkecil kemungkinan hal yang dapat membuat konsentrasi anak terpecah.

Kekurangan Open Education (Aristohadi, 2008)

1. Waktu dan pekerjaan yang berkaitan dengan penyampaian proses pembelajaran jauh lebih banyak daripada proses pembelajaran secara tatap muka.

2. Dukungan administratif untuk proses pembelajaran dibutuhkan untuk melayani jumlah peserta didik yang mungkin sangat banyak.

3. Beberapa peserta merasa terasing karena kurangnya interaksi sosial antarsivitas akademika.

4. Kurangnya struktur dan kebutuhan akan motivasi/inisiatif yang tinggi dapat merupakan tantangan (masalah) bagi peserta.

5. Aktivitas manajemen sekolah umumnya bermutu rendah, sehingga sering mengabaikan masalah akademik, akibatnya kurang peminat.

6. Perlu dukungan media teknologi yang maskimal untuk akses pembelajaran sehingga mampu memotivasi peserta didik untuk lulus pada waktunya.

7. Berubahnya peran pendidik yang tadinya proses pembelajaran secara konvensioanl, sekarang dituntut terampil menggunakan media teknologi pembelajaran.

Kekurangan Deschooling Society (Sumardiono, 2007)

1. Tingkatan sekolahnya masih terbatas.

2. Masih menjadi barang mahal.

3. Perlu tempat yang luas, tempat untuk praktik seperti farming dan outbond. 
4. Masih bercorak agamis, karena menggunakan kurikulum berbasis Islam dipastikan orang-orang non muslim akan enggan untuk menyekolahkan anaknya di sekolah tersebut.

5. Belum adanya standarisasi dari pemerintah untuk melanjutkan ke jenjang yang lebih tinggi.

6. Memerlukan waktu dan sumber dana alternatif.

7. Anak kehilangan kesempatan untuk bersosialisasi dan kurangnya kemampuan kerja sama (team work), organisasi, dan kepemimpinan.

8. Membuat orang tua dapat kehilangan waktu untuk diri sendiri.

9. Diperlukan kesiapan dan pengetahuan ekstra orang tua. Semua orang tua tidak sepenuhnya kompeten di bidang pendidikan.

10. Kurangnya interaksi antara pendidik dan peserta didik bahkan antarsesama peserta didik itu sendiri.

11. Kurangnya interaksi ini bisa memperlambat terbentuknya value dalam proses pembelajaran.

12. Kecenderungan mengabaikan aspek akademik atau aspek sosial dan sebaliknya mendorong tumbuhnya aspek bisnis/komersial.

13. Proteksi berlebihan dari orang tua dapat memberikan efek samping ketidakmampuan menyelesaikan situasi dan masalah sosial yang kompleks dan yang tidak terprediksi.

\section{Pandangan Al Ghazali tentang pendidikan}

Beberapa hal yang patut dipertimbangkan terhadap pandangan Al Ghazali tentang pendidikan, meliputi berikut ini (Rusn, 1998).

a. Terkait perhatian secara penuh pada studi dan tidak diganggu oleh urusan duniawi. Seorang individu tidak mungkin dapat hidup sendiri. Dalam hidup bermasyarakat inilah, setiap individu belajar dari individu lain. Pelajaran diperoleh dari berbagai masalah yang ada di sekelilingnya. Pada dasarnya, setiap permasalahan pasti dipicu oleh urusan duniawi atau nafsu sehingga larangan tersebut terlalu muskil. Satu hal yang perlu diingat bahwa belajar tidak melulu pada aspek kognitif, tetapi juga aspek psikomotorik. Jadi, jika siswa hanya berfokus pada belajar, hal ini justru akan menyebabkan keterkungkungan.

b. Terkait penghormatan pada guru. Hal ini terlalu berlebihan. Walau bagaimana pun, guru juga manusia yang tidak lepas dari kesalahan dan hawa nafsu. Jika siswa tidak diperbolehkan untuk memiliki pendapat, hal itu justru mengekang. Pengekangan ini justru tidak menjadikan siswa kreatif. Padahal salah satu tujuan belajar adalah untuk 
menyelesaikan berbagai permasalahan hidup. Penyelesaian yang diambil tentu saja memerlukan kreativitas dan inovasi. Penyelesian suatu masalah tidak bersifat stagnan, tetapi mengikuti perkembangan.

c. Terkait menghindari diri dari kontroversi akademik. Dalam dunia akademik, kontroversi merupakan hal yang wajar. Jika siswa dilarang memiliki perbedaan pendapat, hal itu justru akan menjadikan ilmu tidak berkembang. Salah satu perkembangan ilmu dikarenakan adanya perbedaan. Perbedaan-perbedaan inilah yang dapat memperkaya pengetahuan, wawasan, pengalaman, dan ilmu seseorang.

\section{Referensi}

Aristohadi. (2008). Konsepsi Pendidikan Terbuka.http://aristohadi.wordpress.com. 15 Oktober 2008, 19.55 WIB.

Freire, P. et al. (1999). Menggugat Pendidikan, (terj.) Omi Intan Naomi. Yogyakarta : Pustaka Pelajar.

Gutek, G.L. (1974). Philosophical Alternatives in Education. USA: Charles E. Merrill Publishing Company.

Brameld, T. (1971). Patterns of Educational Philosophy: Divergence and Convergence in Culturological Perspective. New York: Holt, Rinehart, and Winston.

Hamalik, O. (2007). Dasar-dasar Pengembangan Kurikulum. Bandung: PT. Remaja Rosdakarya.

Helms, D.B., \& Turner, J.S. (1981). Exploring Child Behavior. New York: Holt \& Rinehart.

Rusn, A.I. 1998. Pemikiran al-Ghazali tentang Pendidikan. Yogyakarta: Pustaka Pelajar.

Sukmadinata, N.S. (2007). Landasan Psikologi Proses Pendidikan. Bandung: Remaja Rosdakarya.

Sukmadinata, N.S. (2007). Pendidikan Dasar. Rujukan Filsafat, Teori, dan Praksis Ilmu Pendidikan. Bandung: Universitas Pendidikan Indonesia.

Sumardiono. (2007). Homeschooling, Lompatan Cara Belajar. Jakarta: PT. Elex Media Komputindo.

Supratiknya. 2014. Membaca Pemikiran Driyarkara tentang Pendidikan di Zaman Sekarang.Yogyakarta: Universitas Sanata Dharma.

Suratman, D. (1985). Ki Hadjar Dewantara. Jakarta: Majelis Pendidikan dan Kebudayaan.

Undang-undang Nomor 20 Tahun 2003 tentang Sistem Pendidikan Nasional. 
Woolfolk, A. (2009). Educational Psychology: Active Learning Edition Bagian Kedua. Yogyakarta: Pustaka Pelajar. 
1. Apa Personal Philosophy of Education Anda? Silakan ditulis secara singkat, namun memadai disertai alasan Anda memilih Personal Philosophy of Education tersebut. Ditulis pada lembar tersendiri.

Pendidikan harus mengajarkan peserta didik tentang makna-makna dari al Qur'an dan penciptaan dengan cara bertahap, dan memberi tahu mereka bagaimana untuk menjadi manusia sempurna dengan berjuang meraih kesempurnaan spiritual. Pendidik harus berperan dalam membimbing peserta didik menuju derajat yang lebih tinggi dengan menjelaskan al Qur'an dan alam semesta sebagai sumber berpikir, afektif dan psikomotorik dalam kehidupan intelektual, sosial dan budaya mereka. Pendidik memperlihatkan secara rinci bagaimana menuju kehidupan yang seimbang dan baik dalam setiap aktivitas belajar.

Peserta didik diharapkan dapat mencapai dunia spiritual tertinggi dengan sayap kewalian, kesalehan individu dan sosial, kebaikan, pengetahuan dan sains. Metode pendidikan selain untuk mesucikan diri, juga harus bersifat universal, dan mengembangkan hati, pikiran, ruh dan jiwa peserta didik menuju tingkat yang ideal. Pendidik menghormati dan mengilhami nalar, membimbing nalar menuju tingkatan tertinggi di bawah intelek al Qur'an. Ini berarti proses pendidikan harus membangun ilmu pengetahuan dan mengeksploitasi sumber daya alam dengan menemukan hukum-hukum alam Ilahiah dan merenungi fenomena alam. Sembari melakukan hal ini, pendidikan harus mencari keridhaan Allah dan melaksanakan ajaran al Qur'an. Kesalehan, karakter terpuji dan ketaatan yang ideal hanya mungkin melalui pengetahuan dalam proses belajar. Membatasi pengetahuan hanya pada keilmuan yang kosong dari refleksi dan investigasi mengakibatkan penderitaan, kemiskinan dan kehinaan sebagai manusia.

Kesempurnaan pendidik tergantung kepada kebesaran dari cita-citanya dan dimensi kuantitatif dan kualitatif dari pendengarnya. Kebesaran pendidik juga tergantung kepada kesinambungan prinsip-prinsipnya. Pendidik memperhatikan semua kapasitas spiritual dan mental peserta didik, dan mengembangkannya, mengalihkannya ke dalam tauladan kebaikan. Artinya proses pendidikan supaya berhasil harus dilakukan dengan cara mendidik dengan contoh. Dalam masa sekarang, abad 21, pendidikan harus terintegrasi dan interkoneksi antara ayat-ayat al Qur'an dan ayat-ayat di alam semesta sebagai sunnatullah atau hukum alam. Materi kurikulum harus dikemas sehingga tidak terjadi dikotomi keilmuan lagi. Perilaku pendidik dan peserta didik harus mampu memberikan inspirasi dan berkah kepada lingkungan di sekitarnya. 
Sebagai pendidik harus mempunyai kompetensi kebaikan, antara lain sebagai berikut: (1) memperhatikan dengan sungguh-sungguh kepada semua aspek dari pikiran, ruh dan diri peserta didik, serta mengangkatnya kepada kesempurnaan yang sepantasnya. Manusia yang menyuruh kejahatan ini ingin agar peserta didik tersebut mengabaikan kemampuan yang diberikan Allah untuk mengangkat perasaan, pikiran dan ruh mereka, (2) sebuah sistem pendidikan dinilai berdasarkan universalitasnya, kelengkapan dan kualitas peserta didiknya. Peserta didik harus siap untuk menyampaikan keilmuannya ke seluruh dunia, dan (3) sebuah sistem pendidikan dinilai berdasarkan kemampuannya untuk mengubah murid-muridnya. Murid-muridnya bisa berkembang, tumbuh dan hidup secara intelektual, sosial dan budaya dengan karakter yang istimewa. Peserta didik mampu menumbuhkan sifat-sifat terpuji dalam kehidupan sehari-harinya dan bermanfaat bagi lingkungan keluarga dan masyarakat di sekitarnya.

Pembangunan karakter tidaklah cukup hanya dengan penetapan tujuan pembelajaran, tetapi perlu dilanjutkan dan ditransformasikan dengan proses yang terus-menerus sepanjang hidup melalui belajar dan gerak ibadah. Melalui proses pendidikan ini, peserta didik akan mampu memvisualisasikan prinsip hidupnya, yaitu pembangunan mental, intelektual, emosi, dan spiritual untuk selalu dapat menemukan pemecahan masalah-masalah kehidupan. Hal ini juga membantu mereka untuk lebih menyeleraskan nilai-nilai positif keilmuan dan keimanan dengan realitas kehidupan.

Kepekaan emosi peserta didik sebagai sumber energi harus dibangkitkan untuk menyulut kreativitas, kolaborasi, inisiatif dan transformasi. Adapun Penalaran logis berfungsi untuk mengantisipasi dorongan-dorongan keliru, untuk kemudian menyelaraskannya dengan proses kehidupan dengan sentuhan manusiawi. Penanaman nilainilai dan karakter kepada peserta didik dalam hidup ini tidak berakar pada intelektual saja tetapi pada kemampuan emosional dan spiritual melalui proses pembelajaran yang berkualitas dengan memaksimalkan lingkungan yang ada.

Hal-hal terkait dengan proses belajar mengajar yang terkait dengan kecakapan emosional dan spiritual, seperti konsistensi (istiqomah), kerendahan hati (tawadhu), berusaha dan berserah diri (tawakal), ketulusan (keikhlasan), totalitas (kaffah), keseimbangan (tawazun), integritas dan penyempurnaan (ihsan) itu akhlakul karimah yang harus ditanamkan dalam proses pendidikan. Terintegrasinya akhlakul karimah dalam kurikulum, baik pada pendidik maupun peserta didik, begitu juga dalam metode mengajar merupakan hal yang efektif dan efisien untuk mencapai tujuan pembelajaran bermakna. Untuk mengantisipasi dan menyeimbangkan sisi emosisonal pendidik dan peserta didik, 
perlu pengalaman-pengalaman positif sebagai penawar atau penyelaras yang dapat menetralkan kembali dampak lingkungan yang telah mempengaruhi hati serta pikiran mereka.

Alasan memilih Personal Philosophy of Education adalah :

“Dialah yang mengutus kepada kaum yang buta huruf seorang Rasul di antara kamu, yang membacakan ayat-ayatNya kepada mereka, mensucikan mereka dan mengajarkan kepada mereka Kitab dan Hikmah (Q.S. 62:2). Rekonstruksionisme sosial/kultural merupakan salah satu filsafat pendidikan yang tepat untuk dijadikan alasan pemilihan tersebut di atas. Hal ini karena falsafah yang dianut memiliki dua ide, yakni pembelajar aktif dalam merekonstruksi pengetahuannya sendiri dan bahwa interaksi sosial penting untuk merekonstruksi pengetahuan. Pendidikan rekonstruksionis berfokus pada sumber-sumber pengetahuan sosial dan kultural. Pengajaran di kelas sebagai sebuah komunitas yang tugasnya mengembangkan pengetahuan. Pengetahuan merupakan hal yang tidak terpisah dari aktivitas penghasil pengetahuan. Oleh karena itu, pengetahuan bersifat transaksional. Pengetahuan dikonstruksi secara sosial dan disebarkan di kalangan sesama partisipan. Peran pembelajar adalah berpartisipasi dalam praktik atau latihan yang juga ikut berkembang. 
